Jurnal Riset Biologi dan Aplikasinya
https://journal.unesa.ac.id/index.php/risetbiologi

\title{
Analysis Condition of Coral Reef Covering in Pramuka Island Waters, Seribu Islands using Line Intercept Transect (LIT) Method
}

\author{
Analisis Kondisi Tutupan Terumbu Karang di Perairan Pulau Pramuka, Kepulauan Seribu \\ menggunakan Metode Line Intercept Transect (LIT)
}

\section{Rega Permana*, Nora Akbarsyah, Pringgo K. D. N. Y Putra, Aulia Andhikawati \\ Department of Fisheries, Faculty of Fisheries and Marine Science Universitas Padjajaran}

\section{Article History}

Received : 11 September 2020 Approved : 25 September 2020 Published : 30 September 2020

Keywords: Coral reef, Line Intercept Transect, seribu islands

Kata Kunci: Terumbu karang, Line Intercept Transect, kepulauan seribu

Abstract

The coral reef ecosystem is one of the typical tropical ecosystems with high biodiversity which has an important role both biologically, ecologically, physically as well as socially and economically. Several coral reef areas in Indonesia were reported to have suffered damage, not only due to climate change which has an impact on rising sea surface temperatures and ocean acidification but also due to anthropogenic factors and irresponsible management of marine tourism. This study aimed to analyze the condition of coral reefs based on covering in Pramuka Island, which is one of the famous tourist destinations in the Seribu Islands. The study was conducted using Line Intercept Transect (LIT) method at predetermined coordinate points. The results showed that the dominant coral reef life form was Acropora Submassive (ACS), namely 18.9\%, and Acropora Branching (ACB) as much as 12.48\%. Besides, the types of life forms found were coral foliase (9.42\%), Miliepora Coral (9.2\%), Coral Massive (4.8\%), Acropora Encrustring (4.24\%), and so on. Based on the results of this study, it can be concluded that the condition of coral reefs in Pramuka Island is still relatively good with a total coral cover percentage of $72.38 \%$. Efforts to protect the coral reef ecosystem in this area need to be considered so that its condition can be maintained.
\end{abstract}

\begin{abstract}
Abstrak
Ekosistem terumbu karang merupakan salah satu ekosistem khas kawasan tropis dengan keanekaragaman hayati tinggi yang memiliki peranan penting baik secara biologis, ekologis, fisika maupun sosial dan ekonomi. Beberapa kawasan terumbu karang di Indonesia dilaporkan mengalami kerusakan selain karena perubahan iklim yang berdampak pada naiknya suhu permukaan air laut dan pengasaman laut, namun juga karena faktor anthropogenic dan pengelolaan pariwisata bahari yang tidak bertanggung jawab. Penelitian ini bertujuan untuk menganalisis kondisi terumbu karang berdasarkan penutupan di Pulau Pramuka yang merupakan salah satu pulau destinasi wisata di Kepulauan Seribu. Penelitian dilakukan dengan menggunakan metode Line Intercept Transect (LIT) di titik koordinat yang telah ditentukan. Hasil penelitian menunjukkan jenis terumbu karang yang mendominasi adalah Acropora Submassive (ACS) yaitu sebanya 18.9\% dan Acropora Branching (ACB) sebanyak $12.48 \%$. Selain itu jenis life form yang ditemukan seperti coral foliase (9,42\%), Coral Miliepora (9,2\%), Coral Massive (4,8\%), Acropora Encrustring (4,24\%) dan lain sebagainya. Berdasarkan hasil penelitian ini dapat disimpulkan bahwa kondisi terumbu karang di Pulau Pramuka masih tergolong baik dengan persentase total tutupan karang sebesar 72,38\%. Upaya penjagaan ekosistem terumbu karang di wilayah ini perlu diperhatikan supaya kondisinya dapat terus terjaga.
\end{abstract}

How to cite: Permana, R., Akbarsyah, N., Putra, P. K. D. N. Y., \& Andhikawati, A. (2020). Analysis Condition of Coral Reef Covering in Pramuka Island Waters, Seribu Islands using Line Intercept Transect (LIT) Method. Jurnal Riset Biologi dan Aplikasinya, 2(2): 77-81. 


\section{INTRODUCTION}

Coral reef ecosystem is one of the ecosystems with the highest biodiversity among other ecosystems (Adey, 2000). In addition, this ecosystem also plays an important ecological role, both biologically and physically as a barrier protective for coastal areas (Moberg \& Forke, 1999; Dahuri, 2000). Currently, coral reef ecosystems, especially in tropical waters, face various threats, such as the impact of climate change, namely an increase in sea water temperature and ocean acidification which causes coral bleaching (Baker et al., 2008). In addition, anthropogenic impacts resulting from human activities are also a threat factor for coral reef ecosystems, including chemical pollution, use of non-environmentally friendly fishing gear and irresponsible tourism activities (Edinger et al., 1998; Jones, 2007; Biggs, 2011).

Indonesia is one of the countries with the most extensive coral cover in the world, especially in the eastern part of Indonesia where there is the center of the coral triangle (Coral Triangle Center) together with five other countries, namely Malaysia, the Philippines, Papua New Guinea, Timor Leste and the Solomon Islands (Clifton, 2009). Based on geographic information obtained from satellites, the total area of coral reefs in Indonesia is around 2.5 million hectares (Hadi et al., 2009). Of the total area, only about $6.56 \%$ were in the very good category while the rest were in the good category $(22.96 \%)$, moderate $(34.3 \%)$ and bad $(36.18 \%)$. Although there are still many local coral reef communities showing very rapid recovery, various surveys show that average live coral cover is decreasing periodically. This is because disturbance or threats to coral reefs are almost always faster than their recovery rate.

The Seribu Islands Cluster which is located in DKI Jakarta Province, especially Pramuka Island, which is the center of administrative activities in the Seribu Islands, has been reported to experience high environmental pressure, especially from waste pollution and tourism. According to research conducted by Suhery et al. (2017), the coral reef ecosystem on Pramuka Island was in the medium category in the context of vulnerability to oil spills. This was based on the location of the island, which was in the route of Tanjung Priok Port and the Indonesian Archipelago Sea Channel I (ALKI I). Therefore, this study aimed to determine the condition of coral reefs in Pramuka Island as seen from their cover through the method Line Intercept Transect (LIT). Apart from being relatively easy, this method has also been widely used in the analysis of the condition of coral reef ecosystems (Sarbini et al., 2016; Wahib, 2019).

\section{MATERIALS AND METHODS}

The research was conducted using the method Line Intercept Transect(LIT) along 50 meters at a depth of 3-6 meters consisting of one transect. Determining the location of the observation station based on purposive sampling technique. The research used Manta tow method, which was conducted by snorkeling around the observation location to determine the data collection point (Sukmara et al., 2001). Observations were then carried out along the 50-meter transect by recording the types of life forms found.

The types of life form observed include: Coral Foliose (CF), Acropora Submassive (ACS), Acropora Branching (ACB), Coral Milepora (CME), Coral Massive (CM), Acropora Encrusting (ACE), Coral Encrusting(CE), Coral Submassive (CS), Acropora Digitate (ACD), Coral Tubipora (CTU), Coral Mushroom (CMF) and also life forms other than coral,namely Sponge (SP), Rubble (RB), Dead Coral(DC), and Dead Coral with Algae(DCA) (UNEP, 1993).

Calculation of coral reef cover is then continued by calculating the area of cover using a simple mathematical equation, namely:

$$
\% \text { Cover }=\frac{\text { Total Life Form cover }(\text { Life })}{\text { Total Transect Length }} \times 100 \%
$$

Furthermore, the percentage of live coral cover is categorized according to the coral reef condition category according to Yuliani et al. (2016) which are divided into five categories, namely:

(1) Very Bad Category: $0-10 \%$

(2) Bad Category: $11-30 \%$

(3) Medium Category: $31-50 \%$

(4) Good Category: $51-75 \%$

(5) Very Good Category: $76-100 \%$

\section{RESULTS AND DISCUSSION}

The condition live coral on the coast of Pulau Pramuka, Seribu Island with the LIT method, found the Percent Life Coral Life Form value of $72.38 \%$ which is in the good category for the distribution of corals along the transect line, which is about $50 \mathrm{~m}$. From the data obtained, the percentage value of coral cover from the most consecutive was Acropora submassive (ACS) with a value of $18.9 \%$ and Acropora Branching (ACB) with a value of $12.48 \%$, after that Coral Foliose $(\mathrm{CF})$ which looks 
like a sheet leaves with a value of $9.42 \%$, then Coral Milepora (CML) or fire coral which can be recognized by the presence of a yellow color at the end of the colony, amounting to $9.2 \%$, Coral Mushroom (CMF) $4.88 \%$, Coral Massive (CM) $4.8 \%$, Acropora Encrusting(ACE) 4.24\%, Coral Milepora (CME) $3.86 \%$, Dead coral still covered with algae (DCA) by $3.44 \%$, other types of organisms ( OT) such as sea urchins as much as $2.34 \%$, as for dead corals (DC) as much as $1.9 \%$, then there is Coral Encrusting(CE) 1.8\%, Coral Submassive (CS) $1.72 \%$, Acropora Digitate (ACD) 1\%, Sponge (SP) 0.9\%, Coral Tubipora (CTU) 0.08\%, and Rubble (RB) $\quad 0.04 \%$. The cover of all life forms observed, both living and not visible in Table 1.

Table 1. Observation results of Life form at Pramuka Island Beach, Seribu Islands.

\begin{tabular}{ccc}
\hline Life Form & Total Length $(\mathrm{m})$ & $\begin{array}{c}\text { Percentage } \\
(\%)\end{array}$ \\
\hline CF & 4.71 & 9.42 \\
CML & 4.6 & 9.2 \\
CMF & 2.44 & 4.88 \\
CM & 2.4 & 4.8 \\
CS & 0.86 & 1.72 \\
CME & 1.93 & 3.86 \\
CE & 0.9 & 1.8 \\
CTU & 0.04 & 0.08 \\
ACE & 2.12 & 4.24 \\
ACD & 0.5 & 1 \\
ACB & 6.24 & 12.48 \\
ACS & 9.45 & 18.9 \\
RB & 0.02 & 0.04 \\
DC & 0.95 & 1.9 \\
DCA & 1.72 & 3.44 \\
OT & 1.17 & 2.34 \\
SP & 0.45 & 0.9 \\
\hline & & \\
\hline
\end{tabular}

The dominant coral type in a habitat depends on environmental conditions or the habitat where the coral lives (Daniel \& Santosa, 2014). In habitat, the type of coral that is alive can be dominated by a certain type of coral. It can be seen that the live corals that dominate the Pramuka island waters are Acropora Sub massive (ACS) and Acropora Branching (ACB). This was influenced by environmental conditions that are not far from the coastline, where this area usually gets higher environmental pressure such as currents and strong waves and pollution from the land. Besides, at this location, the condition of the ecosystem is still good and the type of hard substrate is still supportive and there is nocover sand (S) which can cause poor sedimentation because the sand when exposed to high currents will carry a substrate that can bury coral reefs (Adriman et al., 2013). because the type of Acropora grows in clear waters and there are wave breaks (Sembiring \& Trianto, 2018). The results of the average percentage of live coral cover in Pramuka Island, Kepulauan Seribu can be seen in Figure 1.

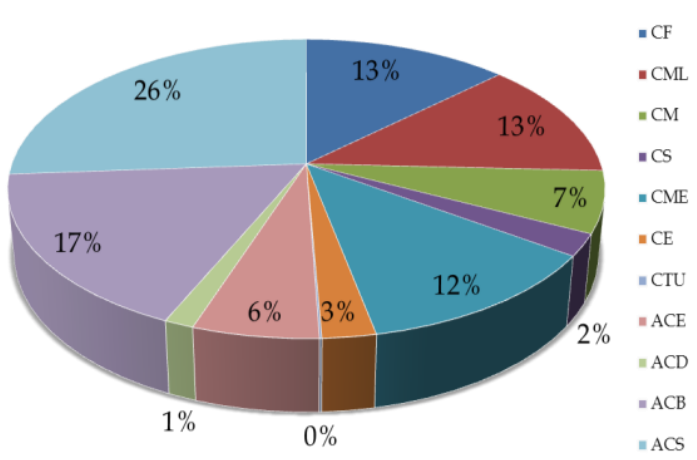

Figure 1. Analysis of the Percentage of Coral Cover Live in Pramuka Island Waters

The Current parameter at the research location is quite high because it is influenced by the conditions of its open waters and strong winds. The existence of currents and waves in the waters is very important for the survival of coral reefs. The current is needed to bring food in the form of plankton; besides that, it also cleans itself from sediments and to supply oxygen from the free sea. Therefore, growth in a place where the water is constantly being stirred up by currents and waves is preferable to calm, sheltered waters.

The appearance of Dead Coral with Algae (DCA) can be predicted that the dead coral is a type of coral that cannot adapt to strong currents. The emergence of sponges (SP) can also be a serious threat, although only $0.9 \%$ were identified, because they live on corals and become coral "drillers" (Tioho \& Roeroe, 2002). Several species are dangerous endolites that can damage coral reefs. In addition to their ability to "drill" sponge coral, they also produce siphonodictine compounds, which can inhibit the growth of coral polyps (Sullivan et al, 1983).

In addition, there are also coral fractures around the transect, the existence of coral fractures at this dive station is thought to be caused by high 
boat traffic along the area, the release and towing of anchors who do not pay attention to the presence of corals and the behavior of divers who easily break the coral. All of these activities fall into the anthropogenic category, namely damage caused by humans.

Human threats to coral reefs can be detected by looking at visible indications and possible treatments. Threats to the coral reef ecosystem can also be caused by natural factors. Threats by nature can include hurricanes, tsunami storms, earthquakes and global warming that causes coral bleaching. In addition, predation by COT (crown-of-thorns starfish) can also be a threat to coral reefs (Vogler et al., 2008). To support the sustainable use of corals, artificial coral breeding can be carried out by endeavoring for conservation, including by performing coral transplants.

\section{CONCLUSION}

It can be concluded that the condition of coral reefs in Pramuka Island was classified as good with a percentage of coral cover of $72.38 \%$. The type of coral reef that dominates was Acropora Submassive(ACS), which was $18.9 \%$ and Acropora Branching (ACB) at $12.48 \%$. In addition, other types of coral were also found such as Coral Foliose (CF), Coral Milepora (CML) or fire coral, $\mathrm{CMF}$, Massive Coral (CM), Acropora Encrusting (ACE), CME or the same as CML, namely Milepora Coral, Dead Coral which are still covered with algae (DCA), other types of organisms (OT) such as sea urchins, as for dead corals (DC), Coral Encrusting (CE), Coral Submassive (CS), Acropora Digitate (ACD), Sponge (SP), Coral Tubipora (CTU), and Rubble (RB).

\section{REFERENCES}

Adey, W. H. (2000). Coral reef ecosystems and human health: Biodiversity counts! Ecosystem health, 6(4), 227236. 10.1046/j.1526-0992.2000.006004227.x.

Adriman, Purbayanto, A., Budiharso, S., \& Damar, A. (2013). Pengaruh Sedimentasi Terhadap Terumbu Karang di Kawasan Konservasi Laut Daerah Bintan Timur Kepulauan Riau. Berkala Perikanan Terubuk, 41(1), 90101.https://doi.org/http://dx.doi.org/10.31258/teru buk.41.1.90-101.

Baker, A. C., Glynn, P. W., \& Riegl, B. (2008). Climate change and coral reef bleaching: An ecological assessment of long-term impacts, recovery trends and future outlook. Estuarine, coastal and shelf science, $80(4), 435-471$.

https://doi.org/10.1016/j.ecss.2008.09.003.

Biggs, D. (2011). Understanding resilience in a vulnerable industry: The case of reef Tourism in Australia. Ecology and Society, 16(1).
https://doi.org/10.5751/ES-03948-160130

Clifton, J. (2009). Science, funding and participation: Key issues for marine protected area networks and the Coral Triangle Initiative. Environmental Conservation, $36(2)$ 91-96. https://doi.org/10.1017/S0376892909990075.

Dahuri, R. (2000). Kebijakan dan strategi pengelolaan terumbu karang Indonesia. Prosiding pengelolaan dan IPTEK terumbu karang Indonesia, 1-16.

Daniel, D., \& Santosa, L. W. (2014). Karakteristik Oseanografis dan Pengaruhnya Terhadap Distribusi dan Tutupan Terumbu Karang di Wilayah Gugusan Pulau Pari, Kabupaten Kep. Seribu, DKI Jakarta. Jurnal Bumi Indonesia, 3(2). http://lib.geo.ugm.ac.id/ojs/index.php/jbi/article/vie $\mathrm{w} / 594 / 567$

Edinger, E. N., Jompa, J., Limmon, G. V., Widjatmoko, W., \& Risk, M. J. (1998). Reef degradation and coral biodiversity in Indonesia: Effects of land-based pollution, destructive fishing practices and changes over time. Marine Pollution Bulletin, 36(8), 617-630. https://doi.org/10.1016/So025-326X(98)00047-2

Hadi, T. ., Giyanto, Prayudha, B., Hafizt, M., Budiyanto, A., \& Suharsono. (2009). Terumbu Karang Indonesia. 39. http://oseanografi.lipi.go.id/haspen/buku status karang 2018 digital.pdf.

Jones, R. J. (2007). Chemical contamination of a coral reef by the grounding of a cruise ship in Bermuda. Marine pollution bulletin, 54(7): 905-911. https://doi.org/10.1016/j.marpolbul.2007.02.018.

Moberg, F., \& Folke, C. (1999). Ecological goods and services of coral reef ecosystems. Ecological economics, 29(2), 215-233. https://doi.org/10.1016/S09218009(99)00009-9

Sarbini, R., Kuslani, H., \& Nugraha, Y. (2016). Teknik pengamatan tutupan terumbu karang dengan menggunakan transek garis (line intercept transect) di Pulau Kumbang Kepulauan Karimun Jawa. Buletin Teknik Litkayasa, 14(1), 33-42. https://doi.org/http://dx.doi.org/10.15578/btl.14.1. 2016.33-42

Sembiring, Y. B., \& Trianto, A. (2018). Studi Densitas Dan Komposisi Jenis Juvenil Karang Pada Substrat Pecahan Karang Di Perairan Pulau Sambangan , Karimunjawa. Journal of Marine Research, 7(4), 248256.https://ejournal3.undip.ac.id/index.php/jmr/arti cle/view/25923/23113

Suhery, N., Damar, A., \& Effendi, H. (2017). Indeks Kerentanan Ekosistem Terumbu Karang Terhadap Tumpahan Minyak" Kasus Pulau Pramuka dan Pulau Belanda di Kepulauan Seribu. Jurnal Ilmu Dan Teknologi Kelautan Tropis, 9(1), 67-90. https://journal.ipb.ac.id/index.php/jurnalikt/issue/vi ew/ 1919.

Sukmara, A., Siahainenia, A. ., \& Rotinsulu, C. (2001). Panduan Pemantauan Terumbu Karang BerbasisMasyarakat dengan Metoda Manta Tow (I). https://www.crc.uri.edu/download/MAN_0033.pdf. 
Sullivan, B., Faulkner, D. J., \& Webb, L. (1983). Siphonodictidine, a metabolite of the burrowing sponge Siphonodictyon sp. that inhibits coral growth. Science, 221(4616),

1175-1176. 10.1126/science.22 1.4616.1175.

Tioho, H., \& Roeroe, K. A. (2002). Kerusakan Terumbu Karang Akibat Proses Biologis. Ekoton, 2(1), 55-59. https://ejournal.unsrat.ac.id/index.php/EKOTON/ar ticle/view/263/209

Vogler, C., Benzie, J., Lessios, H., Barber, P., \& Wörheide, G. (2008). A threat to coral reefs multiplied? Four species of crown-of-thorns starfish. Biology Letters, 4(6), 696-
699. https://doi.org/10.1098/rsbl.2008.0454

Wahib, N. K. (2019). Kajian Efektivitas Penggunaan Metode Lit, Pit, Dan Qt Untuk Monitoring Tutupan Substrat. JFMR-Journal of Fisheries and Marine Research, 3(3), 331-336.

https://doi.org/10.21776/ub.jfmr.2019.003.03.7

Yuliani, W., Ali, M., \& Saputri, M. (2016). Pengelolaan Ekosistem Terumbu Karang oleh Masyarakat di Kawasan Lhokseudu Kecamatan Leupung Kabupaten Aceh Besar. Jurnal Ilmiah Mahasiswa Pendidikan Biologi, 147(1), 11-40. 